\title{
Medico-legal investigation of a series of female murders in Sabaragamuwa Province, Sri Lanka
}

Muditha Vidanapathirana ${ }^{1}$, Rohan P Ruwanpura ${ }^{2}$, Ruwan J Illeperuma ${ }^{3}$ Uthpala Attygalle ${ }^{4}$, Prasanna B Dasanayake ${ }^{4}$, Handun Wijewardene ${ }^{4}$, Tikiri KMB Gunathilake ${ }^{*} \Delta(\mathrm{D}) \mathrm{Kamal} \mathrm{WMB}^{*}$ Wijetunga ${ }^{4}$, Inoka Rathnayake ${ }^{4}$

${ }^{1}$ Department of Forensic Medicine, Faculty of Medical Sciences, University of Sri Jayewardenepura, Sri Lanka,

${ }^{2}$ Office of the Judicial Medical Officer, Teaching Hospital, Karapitiya, Galle, Sri Lanka, ${ }^{3}$ Genetech Molecular Diagnostics, Colombo 08, Sri Lanka,

${ }^{4}$ Consultant JMO, Provincial General Hospital, Ratnapura, Sri Lanka,

\section{Background}

From 2008-2015, several female murders were reported from Sabaragamuwa, Sri Lanka. The motive of most killings was not obvious and the attacks were targeted against isolated, elderly females. This study was conducted to analyze the medico-legal aspects of those female murders.

\section{Methods}

Data of females who had been killed under similar circumstances in Kahawatta, Ratnapura were collected from July 2008 to Dec 2015.

\section{Results}

There were 17 female murders. Ten dead bodies were left at the scene and remaining seven were moved. The cause of deaths had been cut injuries to the head $(n=12)$ and blunt force trauma to the head $(n=2)$, ligature strangulation $(n=2)$ and manual strangulation $(n=1)$. There were three double murders. The first double murder and Case 15 and 16 were due to personal enmities. Suspect arrested in 2010 was a paraphilic and claimed for 3 murders with no DNA matches. Suspect arrested in 2015, was responsible for six murders and DNA of three identical post-coital samples matched with his DNA. Features such as "two or more" "independent", "planned" murders committed at "separate locations' for 'personal gratification' by the same individual/s, separated by a “cooling-off” period were found in most murders.

\section{Conclusions}

The three special features found in this series were some attempting to mimic serial killings, some appearing to be copycat murders and in other instances appearing to be an alibi created by the suspects who were in the custody. This is the first ever reported instance of two or more serial killers operated in the same area in the same duration.

Keywords: Alibi, copycat murders, mimic serial killer, Sri Lanka

Copyright: @ 2018 with the Medico-legal Journal of Sri Lanka.

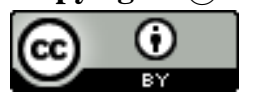

This is an open-access article distributed under the terms of the Creative Commons Attribution 4.0 International License, which permits unrestricted use, distribution and reproduction in any medium

Funding: None provided the original author and source are credited

Competing interests: None

Received: 24 June 2018

Accepted revised version: 15 December 2018 Published: 30 December 2018

*Corresponding author: Gunathilake KMTB, Email: tikiriii_bandara@yahoo.com

https://orcid.org/0000-0002-8485-4550

Cite this article as: Vidanapathirana M, Ruwanpura PR, Illeperuma RJ, Attygalle U, Dasanayake PB, Wijewardene HP, Gunathilake KMTB, Wijetunga WMKB, Rathnayake I . Medico-legal investigation of a series of female murders in Sabaragamuwa Province, Sri Lanka. Medico-Legal Journal of Sri Lanka, 2018; 6(2):55-63.

DOI: http://dx.doi.org/10.4038/mljsl.v6i2.7375 


\section{Introduction}

Kahawatta is a town in Ratnapura district of the Sabaragamuwa province in Sri Lanka. It is situated about $115 \mathrm{Km}$ east of Colombo, the capital city of Sri Lanka. From 2008-2015, a series of women were found to have been killed in Kahawatta by unexpected and unknown attacks. It is necessary to ascertain whether these cases were serial killings, mimic serial killings or copycat murders.

Over the years, researchers and law enforcement professionals have tried to achieve uniformity in the use of the term "serial murder," but such efforts have rather been proven futile. ${ }^{[1]}$ According to the encyclopedia of forensic and legal medicine (2005), serial killing is defined as "three or more" "independent", "planned" murders committed by the "same individual/s", and separated by a "cooling-off" period. ${ }^{[2]}$ It is the "cooling-off" period that separates serial killers from other types of multiple murderers. ${ }^{[2]}$ Adjorlolo and Choon (2014) proposed a more comprehensive definition of serial murder with three key elements: (i) Two or more forensic linked murders, (ii) committed as discrete event/s by the same person/s over a period of time, (iii) where the primary motive is personal gratification. ${ }^{[1]}$ This definition has reduced the minimum number of murders from three to two and introduced 'personal gratification' as a primary objective for committing such crimes.

Further, it is very difficult to link the suspect to the crime because there is no prior relationship existing between the serial killer and the victim, and therefore, the suspects arrested at the initial stage may be completely exonerated later. That is why it is essential to have a higher degree of suspicion and attempt to identify a serial killer/s in such a series of murders. This study analyzes the medico-legal aspects of this series of killings at Kahawatta to determine the nature and characteristics of the circumstances and the killers.

\footnotetext{
Methodology

Data of all the women who were killed in Sabaragamuwa province, Sri Lanka under similar circumstances; unexpected murders by unknown attacks were collected from July 2008 to Dec 2015.

The data were collected from all the forensic practitioners who conducted those autopsies. Further, media reports, data of Scene of Crime Officers (SOCO), police records and court records were also used. Data were collected using a data collection form. Secondary data were collected from journals, textbooks, internet etc.
}

For the purpose of this study, "serial murder" was redefined considering two definitions; the definition of encyclopedia of forensic and legal medicine (2005) and the definition of Adjorlolo and Choon (2014). Therefore, the "serial murder" was re-defined as "two or more" "independent", "planned" murders committed at "separate locations" for "personal gratification" by the "same individual/s" "over a period of time", and separated by a "cooling-off" period.

Ages were classified into 20 years ranges; 10-29, 30$49,50-69$ and $70-89$ years. The location of the incident was classified as "at home" or "outside". The marital state was classified as married, unmarried or cohabiting. Their employments were classified as unemployed/housewives, skilled/ non-skilled labourers and small-scale businesswomen. The numbers of injuries were classified as one, 2-5, 6-10 and more than 10 . Anonymous data about the features of the murders, circumstances and murderers were analyzed and the details of the different variables were revealed. Already available routinely collected data with the investigators, in their capacity as Judicial Medical Officers (JMOs) who performed these postmortems were perused and analyzed. Permission of the Director of the Provincial General Hospital, Ratnapura was obtained to conduct and publish this study. All the necessary precautions were taken to prevent anybody identifying the identity of the victims.

\section{Results}

There were 17 female murders due to unexpected and unknown attacks. All occurred in Sabaragamuwa Province. Of them, 14 in Kotakethana, two in Dimulwala and one in Niladuramahayaya administrative divisions. The exact locations are shown on the map (Fig. 1).

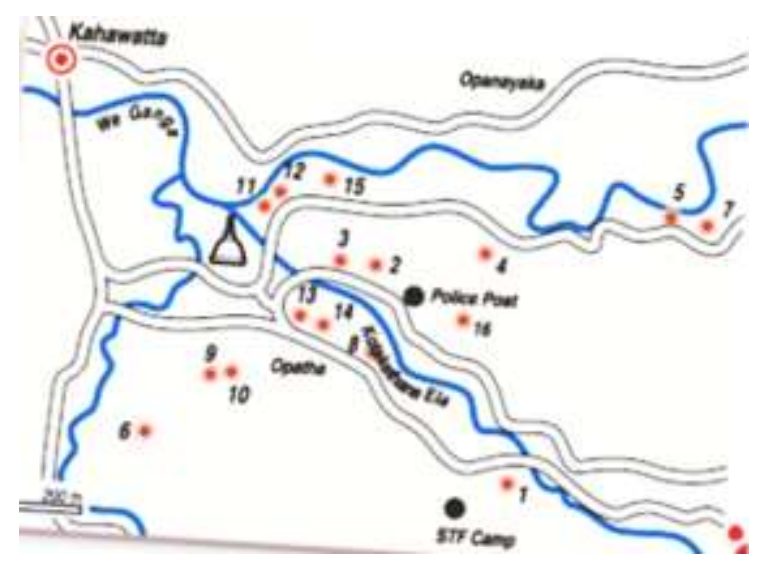


Figure 1. Locations of the murders (Area map with a scale)

Most killings occurred in $2012(\mathrm{n}=07)$ and none in 2009 and 2013. According to the date of the postmortems, the incidence of the murders is shown in Fig. 2.

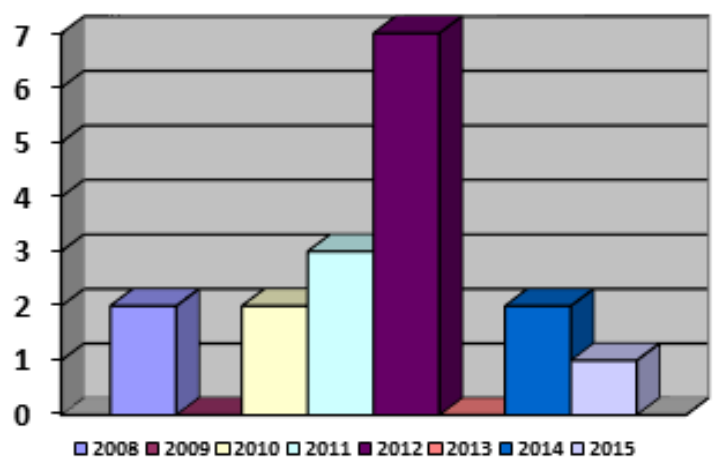

Figure 2. Incidence of murders

In this series, the age groups of the victims, marital status and employment are shown in Table 01. The ages ranged from 19-88 years and 09 belonged to 5069 years age group. The number of married victims was 09 . Ten victims were unemployed/ housewives.

Table 01. Demographic findings

\begin{tabular}{lll}
\hline & Demographic findings & $\begin{array}{l}\mathbf{( N = 1 7 )} \\
\mathbf{n}\end{array}$ \\
\hline Ages & $10-29$ years & $01\left(8^{\text {th }}\right)$ \\
& $30-49$ years & 06 \\
& $50-69$ years & 09 \\
& $70-89$ years & $01\left(4^{\text {th }}\right)$ \\
Marital & Married & \\
status & Cohabiting & 09 \\
& Unmarried & $01\left(15^{\text {th }}\right)$ \\
Employm & Unemployed/housewiv & 10 \\
ent & es & 06 \\
& Labourers & $01\left(16^{\text {th }}\right)$ \\
\hline
\end{tabular}

In single murders, the victims had been living alone and in double murders (DM), there had been only two occupants. The descriptions of each murder (ages of the victims, scene findings, time since death (TSD), date of autopsy, evidence of sexual assault, injuries and the cause of death (COD) is as follows.

$1^{\text {st }}, 2^{\text {nd }}$ and $3^{\text {rd }}$ murders: All were married women who were living alone and the white smoked 'Beedi' were found in all 3 crime scenes.
The $1^{\text {st }}$ deceased was 56 years old. Her skirt was found raised above the thighs. The autopsy was done a day after the death on 23.07.2008. There were abrasions and contusions in the neck and the cause of death (COD) was manual strangulation. There were no exogenous DNA in the vaginal swabs.

The $2^{\text {nd }}$ deceased was 48 years old. The body was recovered from Kotakethana canal in partially skeletonized state 10 days after missing. The autopsy was conducted on 23.11.2008. There were long deep cuts and the COD was cut injuries to the head.

The $3^{\text {rd }}$ deceased was 88 years old. The injured head had been washed and wrapped with a bed sheet. The autopsy was performed a day after the death on 14.06.2010 and revealed genital tears. The body had both blunt and sharp force injuries and the COD was blunt force trauma to head. There were no exogenous DNA in the vaginal swabs.

A 35-year-old suspect was arrested in connection of $3^{\text {rd }}$ murder in 2010 . He was produced before the Consultant Forensic Pathologist, Provincial General Hospital, Ratnapura and the suspect confessed for $1^{\text {st }}$, $2^{\text {nd }}$ and $3^{\text {rd }}$ murders. He admitted that he had an affinity for elderly women and had sexual intercourse with above three women. He was referred to the forensic psychiatrist at Mental Hospital, Angoda, Sri Lanka and it was revealed that he had a paraphilia, a disorder of sexual preference in the form of sadism and necrophilia. However, the vaginal smears of $1^{\text {st }}$ and $3^{\text {rd }}$ did not produce exogenous DNA.

In $4^{\text {th }}$ murder, a 52-year-old married female went missing and the dead body was found buried on next day with a ligature around the neck. The autopsy was done on 23.12.2010 and the COD was ligature strangulation. There were exogenous DNA in the vaginal swabs.

$5^{\text {th }}$ murder: A 66-year-old unmarried woman who lived alone was found dead inside her burnt down the house at Dimulwala, Kahawatta. The autopsy was performed a day after the death on 05.04.2011. There were defence injuries, long cut injuries and the COD was cut injuries to the head. There were no exogenous DNA in the vaginal swabs.

$6^{\text {th }}$ murder: A 44-year-old unmarried woman who was living with her father in Niladuramahayaya, Kahawatta, went missing. Her clothes, undergarments and blood, were found at another site a day after her disappearance. The putrefied body was found after 10 days in the jungle. The autopsy was done on 01.07.2011. There were long slashed cuts and the 
COD was cut injuries to the head. Suspect, a toddy tapper was arrested and he revealed that the victim went to the backyard at around $7.30 \mathrm{pm}$ for a body wash, he had sexual intercourse with her by force and then killed her because she shouted.

In $7^{\text {th }}$ murder, a 69 -year-old female was found killed in the backyard of her house. The autopsy was performed one day after death on 16.12.2011. There were multiple cut injuries including short, deep cut injuries and the COD was cut injuries to head. There were exogenous DNA in the vaginal swabs.

The $4^{\text {th }}$ and $7^{\text {th }}$ murders confirmed the presence of identical male DNA in the vaginal swabs.

$8^{\text {th }}$ and $9^{\text {th }}$ murders ( $1^{\text {st }}$ double murder): A 19-year-old unmarried female was found killed in a tea estate 3 days after she went missing. Her 60 -year-old mother was found dead in her bedroom 4 days after she went missing. Autopsies were performed on $4^{\text {th }}$ and $5^{\text {th }}$ of February 2012 respectively. There were defence injuries on $8^{\text {th }}$ and there were 13 injuries on the $9^{\text {th }}$. There were multiple long, slashed cuts on both and the CODs were cut injuries to the head. The vaginal swabs of both were negative for male DNA. A neighbouring couple and a three-wheeler driver were arrested. Those were alleged to be drug-related killings. According to the alleged history, the 19-year-old daughter had been given a 'lunch parcel' by the neighbour regularly to be handed over to a person in Ratnapura town when she goes to classes. Once, the recipient had not turned up and after returning home, mother and the daughter had opened the 'lunch parcel'. However, they found a packet containing some powder rather than food and the mother blamed the neighbour. Next day, both of them were killed at the house and the daughter's body had been transported to a tea estate by the threewheeler. All 3 suspects were arrested.

$10^{\text {th }}$ and $11^{\text {th }}$ murders ( $2^{\text {nd }}$ double murder): A 51-yearold unmarried woman and her 61-year-old sister who was living in the same house were found dead in their burnt down house. A "curved knife" was found at the scene (Figure 3). Autopsies were performed a day after on 01.06.2012. There were burns but soot was absent in respiratory tracts. The $10^{\text {th }}$ murder had a ligature and a mark around the neck and the COD was ligature strangulation. The $11^{\text {th }}$ murder had more than 10 injuries including defence cuts on upper limbs and multiple long, slashed cuts on the head and the COD was cut injuries to head. The vaginal swabs were negative for exogenous DNA. However, crime scene stains had DNA of a male individual.

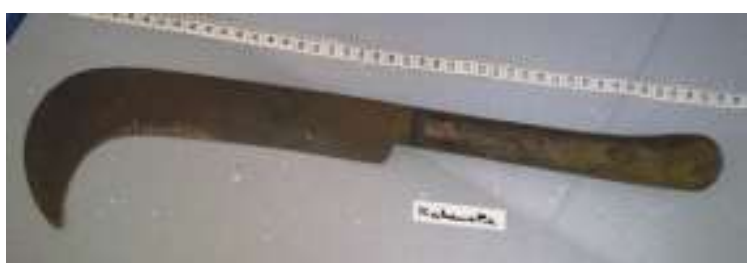

Figure 3. The curved knife

$12^{\text {th }}$ and $13^{\text {th }}$ murders ( $3^{\text {rd }}$ double murder): A 63 -yearold mother and her 35-year-old unmarried daughter were found dead in their burnt down house. Autopsies were performed a day after on 20.07.2012. In the $13^{\text {th }}$ murder, there were several (11) injuries. There were burns but soot was absent in respiratory tracts. There were defence injuries and multiple, long, slashed cuts and the CODs were cut injuries to the head. Mother's vagina had a contusion but was negative for exogenous DNA. The vaginal swab of the daughter $\left(13^{\text {th }}\right.$ murder) confirmed the presence of male DNA. Four (04) suspects were arrested, however, male DNA profiles of vaginal swabs did not match with any of the four suspects arrested, and all were acquitted.

$14^{\text {th }}$ murder: A 66-year-old married woman was killed in her house in Dimulwala and the body was found in the rear garden which was evident by blood tracking. The autopsy was performed a day after on 01.11.2012. There was only one cut and it was short and deep and the COD was cut injury to the head.

$15^{\text {th }}$ murder: A naked dead body of a 31-year-old woman, who was living with a cohabiting male partner, was recovered from Kotakethana canal. Clothes were recovered from a nearby place. Initially, the cohabiting partner was suspected for the killing, but later a neighbour was arrested in connection with an issue related to Kovil. The autopsy was performed a day after on 23.10.2014. There were multiple blunt force injuries including compound depressed comminuted fractures with cerebral injuries and the COD was blunt force injuries to the head. Vaginal swabs were negative for exogenous DNA.

$16^{\text {th }}$ murder: A 39 -year-old mother, who was a smallscale businesswoman, was killed and the body was recovered from the Kotakethana canal. The autopsy was held a day after on 27.12.2014. There were defence cuts on upper limbs and long, slashed cuts on the head and the COD was cut injuries to the head. Later, the son was arrested in connection with this murder. He revealed that he had demanded money to buy a present to his girlfriend and when mother refused, he murdered the mother in the kitchen and dumped her in Kotakethana canal. The vaginal swab was negative for exogenous DNA. 
17 $7^{\text {th }}$ Murder: A 49-year-old mother of two children who was living alone, was found killed. Her undergarments had been cut and removed. The autopsy was done a day after on 28.09.2015. There were 12 injuries including defence injuries in the left hand and long, slashed cuts on the head and the COD was cut injuries to the head. The vaginal swab was negative for exogenous DNA.

Until, November 2015, there had been 11 arrests. A 35 -year-old suspect who was suffering from paraphilia was arrested in 2010 in connection of $3^{\text {rd }}$ murder and he confessed for $1^{\text {st }}, 2^{\text {nd }}$ and $3^{\text {rd }}$ murders. Regarding $6^{\text {th }}$ murder, a toddy tapper was arrested and he confessed for the murder following sexual intercourse. Relevant to $8^{\text {th }}$ and $9^{\text {th }}$ murders $\left(1^{\text {st }}\right.$ double murder) a neighbouring couple and a three-wheel driver were arrested. In connection of $12^{\text {th }}$ and $13^{\text {th }}$ murders $\left(3^{\text {rd }}\right.$ DM), four (04) suspects were arrested, however, male DNA profiles of vaginal swabs did not match with any of the four suspects arrested, and all were acquitted. Regarding $15^{\text {th }}$ murder, initially, the cohabiting partner was suspected for the killing, but later a neighbour was arrested in connection with an issue that had occurred in the Kovil. Relevant to the $16^{\text {th }}$ murder, the son of the deceased was arrested.

Most killings occurred during the night. None of the incidents had eyewitnesses. The number of injuries and the CODs are shown in Table 03.

Table 03: The autopsy findings

\begin{tabular}{lll}
\hline & $\begin{array}{l}\text { Autopsy } \\
\text { findings }\end{array}$ & $\begin{array}{l}\mathbf{n}=17) \\
\mathbf{n}\end{array}$ \\
\hline $\begin{array}{l}\text { Number } \\
\text { of injuries }\end{array}$ & One & $01\left(14^{\text {th }}\right)$ \\
& $2-5$ & $02\left(5^{\text {th }} \& 8^{\text {th }}\right)$ \\
& $6-10$ & 10 \\
Types of & $\begin{array}{l}\text { Cut injuries to } \\
\text { the head }\end{array}$ & 12 \\
CODs & Blunt injuries & $02\left(9^{\text {th }} \& 11,13 \& 17^{\text {th }}\right)$ \\
& to the head $\left.15^{\text {th }}\right)$ \\
& $\begin{array}{l}\text { Ligature } \\
\text { strangulation }\end{array}$ & $02\left(4^{\text {th }} \& 10^{\text {th }}\right)$ \\
& $\begin{array}{l}\text { Manual } \\
\text { strangulation }\end{array}$ & $01\left(1^{\text {st }}\right)$ \\
\hline
\end{tabular}

According to the autopsy findings in Table 03 , four victims $(9,11,13$ and 17) received more than 10 injuries and seven victims had defence injuries $(5,8$, $11,12,13,16$ and 17). The most common COD was the cut injuries to the head $(\mathrm{n}=12)$.
An analysis of the murders is shown in Table 04 . According to the number of murders in each incident, there were three double murders. According to the history, scene findings and DNA findings, the murders could be divided into four clusters and the finding are shown in Table 4.

Table 04: Comparative analysis of the murders

\begin{tabular}{lll}
\hline & $\begin{array}{l}\text { Autopsy } \\
\text { findings }\end{array}$ & $\begin{array}{l}(\mathbf{N}=17) \\
\mathbf{n}\end{array}$ \\
\hline $\begin{array}{l}\text { No of } \\
\text { murders }\end{array}$ & Single murders & 11 \\
& $\begin{array}{l}\text { Double murders } \\
\text { (DM) }\end{array}$ & $\begin{array}{l}03\left(8^{\text {th }} \& 9^{\text {th }}, 10^{\text {th }}\right. \\
\left.\& 11^{\text {th }}, 12^{\text {th }} \& 13^{\text {th }}\right)\end{array}$ \\
$\begin{array}{l}\text { History, } \\
\text { scene \& }\end{array}$ & $\begin{array}{l}\text { (a) Suspects and } \\
\text { reasons were }\end{array}$ & $04\left(1^{\text {st }} \mathrm{DM}\right.$ and \\
DNA & known $\left.16^{\text {th }}\right)$ \\
findings & $\begin{array}{l}\text { (b) Suspects and } \\
\text { reasons not } \\
\text { known }\end{array}$ & \\
& 1) Identical & $03\left(1^{\text {st }}, 2^{\text {nd }} \& 3^{\text {rd }}\right)$ \\
& scene profiles & \\
& 2) Identical & $06\left(4^{\text {th }}, 7^{\text {th }}\right.$ and \\
& DNA profiles & $\left.2^{\text {nd }} \& 3^{\text {rd }} D M\right)$ \\
& 3) Suspect/s not & $04\left(5^{\text {th }}, 6^{\text {th }}, 14^{\text {th }} \&\right.$ \\
& yet finalized & $\left.17^{\text {th }}\right)$ \\
\hline
\end{tabular}

Male DNA isolated from $4^{\text {th }}, 7^{\text {th }}$ and $13^{\text {th }}$ murders and the crime scene stains of $2^{\text {nd }} \mathrm{DM}$ were identical and were screened against a DNA database of having more than one thousand DNA profiles of the suspected and the convicted felons of previous crimes that had undergone DNA testing since 2003 in Sri Lanka. Until October 2015, none of the searches generated a significant hit.

In late November 2015, a 39-year-old suspect was arrested. His DNA profile matched with the vaginal samples of three victims; 4,7 and 13 (of $3^{\text {rd }} \mathrm{DM}$ ) and crime scene stains of $2^{\text {nd }} \mathrm{DM}$. Therefore, he was found responsible for those 6 murders.

\section{Discussion}

The initial suspicion is the most important step of the investigation of serial killings. ${ }^{[3]}$ Some of the special aspects in an investigation include reviewing previous crime scenes, post-mortem photographs, police reports, laboratory reports, victimology information 
and discussing the matter with other investigators. ${ }^{[4]}$ Such a methodology was adopted in this investigation.

There were 17 murders committed in Kahawatta and according to Table 04, there were 04 clusters of murders. In the first cluster $\left(1^{\text {st }}\right.$ double murder, and cases 15 and 16), the killer and reasons were known to the victims and were excluded from "serial murders".

Of the remaining 13 murders that did not have known cause or suspect were potential cases of "serial murders" and were divided into 3 more clusters. Therefore, the $2^{\text {nd }}$ cluster had an identical scene profile with smoked white 'Beedi' at scenes (case 1, 2, and 3). Such distinct or unique behaviours that can be used to link a series of crimes to the same individual is called "signature". ${ }^{[5]}$ In 2010, a suspect was arrested and he claimed for $1^{\text {st }}, 2^{\text {nd }}$ and $3^{\text {rd }}$ murders and was found to be a paraphilic. The $3^{\text {rd }}$ cluster had identical DNA profile (case $4,7,2^{\text {nd }}$ and $3^{\text {rd }}$ double murders). On November 2015, another suspect was arrested and his DNA tallied with vaginal samples of case 4, 7 and 13 of $3^{\text {rd }} \mathrm{DM}$ and crime scene stains of $2^{\text {nd }} \mathrm{DM}$ and was responsible for 6 murders. In the $4^{\text {th }}$ cluster, the suspect/s have not yet been finalized. Are those suspects serial killers?

For the purpose of this research, "serial murder" was re-defined as "two or more", "independent", "planned" murders committed at 'separate locations' for 'personal gratification' by the "same individual/s", "over a period of time" and separated by a "coolingoff" period.

When $2^{\text {nd }}$ and $3^{\text {rd }}$ clusters are considered, both suspects who were arrested in 2010 and 2015 had committed 'two or more' murders. The '2010 suspect' committed 3 murders (case 1,2 and 3) and '2015 suspect' committed 6 murders (case 4, 7, $2^{\text {nd }} \mathrm{DM}$ and $3^{\text {rd }} \mathrm{DM}$ ).

Further, those $09\left(^{\text {nd }}\right.$ and $3^{\text {rd }}$ clusters $)$ were 'independent' murders, because there was no relationship between the victims and the suspects. They were unexpected attacks by unknown offenders.

Moreover, those $09\left(^{\text {nd }}\right.$ and $3^{\text {rd }}$ clusters $)$ were 'planned' murders. In a serial murder, the 'planning' is defined as any action committed by an offender in preparation of murder and involves the accumulation of items for use in the selection of a victim, abduction, murder and disposal. ${ }^{[2]}$ Similarly, in these 2 series, women who were living alone were selected and were killed at night in order to avoid eyewitness. In some instances, the bodies were dumped in distant places to avoid detection.
Though all murders were reported from Kahawatta area, they were committed at separate locations such as Kotakethana $(\mathrm{n}=14)$, Dimulwala $(\mathrm{n}=02)$ and Niladuramahayaya $(n=01)$. Moreover, those 9 murders were committed at 'separate locations' as shown in Fig. 1.

Further, these 2 groups of murders had been done for 'personal gratification'. As we know, sexual murder is common among serial killing. ${ }^{[6]}$ In such cases, there is evidence of violence and sex together. In Kahawatta, such combinations of sexual assaults and gross injuries were seen. Sexual orientation was suspected in 12 cases. In case 1, the skirt was found raised above the knees and in case 3 genital tears were found. The '2010 suspect' expected to have sexual intercourse after killing $1^{\text {st }}, 2^{\text {nd }}$ and $3^{\text {rd }}$ victims (Necrophilia) because paraphilia has both sadism and necrophilia. ${ }^{[6]}$ The male DNA of '2015 suspect' was found in vaginal samples of case 4, 7and 13, and genital contusions were found in case 12, and those indicated him having sexual intercourse with those women. In addition, in case 6 and 17, clothes and undergarments were found separately.

Further, these 2 groups showed that they committed such murders "over a period of time". The "2010 suspect' operated over 2 years from July 2008 to June 2010. The '2015 suspect also operated over about 2 years from Dec 2010 to July 2012.

'Cooling-off' period is the significant break including emotional cooling between two murders. ${ }^{[2]}$ There was evidence of a prolonged cooling off periods among the murders of both 2010 and 2015 suspects. The 2010 suspect's cooling off period between $1^{\text {st }}$ and $2^{\text {nd }}$ murders was about 4 months (from July 2008 to November 2008) and between $2^{\text {nd }}$ and $3^{\text {rd }}$ murders was about $1 \frac{1}{2}$ years (from November 2008 to June 2010). In 2015 suspect's minimum 'cooling off' period was 1 $1 / 2$ months ( between $2^{\text {nd }}$ and $3^{\text {rd }} \mathrm{DMs}$ ) and a maximum of about 1 year (between $4^{\text {th }}$ and $7^{\text {th }}$ murders).

Therefore, the 2010 and 2015 suspects had committed "two or more" "independent", "planned" murders at "separate locations", "over a period of time" for "personal gratification" and separated by a "coolingoff" period. Therefore, those two suspects should be serial killers.

When the $4^{\text {th }}$ cluster of murders was considered, though a toddy tapper accepted the killing of case 6 , it was an independent murder because he was an unknown person and committed for no apparent cause. Case 5, 14 and 17 also had been unexplained attacks by unknown offender/s. Therefore, case 5, 6, 14 and 
17 also showed "independent", "planned" murders "over a period of time" at "separate locations" for "personal gratification" and separated by a "coolingoff" period. Therefore, those could have been committed by a $3^{\text {rd }}$ serial killer/s!

Further, the $2^{\text {nd }}, 3^{\text {rd }}$ and 4 th clusters of murders, showed few additional features specific for serial killings such as naked bodies, multiple severe injuries, the absence of an eyewitness, attack while living alone, modes of disposal were setting fire or dumping in water and leaving a 'signature' at the scene. 'Signature' is defined as the unique combination of methods of operation left at crime scenes of serial sexual homicides. ${ }^{[7,8]}$ In one such series of murders, postmortem enucleation of the eyes was the signature. ${ }^{[9]}$ In the current series, the "signature" was that all were isolated, old or elderly women, killed with head injury with sharp weapons. Further, crime scene 1, 2 and 3 had smoked white 'Beedi' at the scene. These reiterate that there should be 2 or more serial killers in Kahawatta, Sri Lanka.

There were three double murders (DM) and all were committed in 2012 due to sharp force injuries to the head. In the $1^{\text {st }} \mathrm{DM}$, the bodies were not burnt and male DNA could not be isolated. Further, the murderers were known to the victims and allegedly connected to a drug deal, and therefore, excluded from serial killing. However, in the $2^{\text {nd }}$ and $3^{\text {rd }} \mathrm{DMs}$, the victims were killed and then burnt. Though the bodies were found severely burnt, the male DNA profile was found in crime scene samples of $2^{\text {nd }} \mathrm{DM}$ and vaginal samples in $13^{\text {th }}$ murder and was tallied with ' 2015 suspect'.

Sometimes, cases may be missed as the same killer moved to different areas and separate investigations are done on the same killer without coordination. This is called linkage blindness. ${ }^{[10]}$ To overcome this, the crime division of the Ratnapura police, set up a separate unit to investigate the killings in Kahawatta.

When considered the suspects, until April 2015 eleven (11) were arrested in relation to ten (10) killings. A paraphilic person in relation to case 1, 2 and 3, a toddy tapper claimed for case 6 , neighbouring couple and a three-wheel driver in $1^{\text {st }} \mathrm{DM}$, and four suspects in $2^{\text {nd }}$ DM. Regarding $15^{\text {th }}$ murder, a neighbour was arrested in connection with an issue that had occurred in the Kovil. Then the deceased's son in case 16. Finally, the DNA profile of the suspect arrested in 2015 tallied with 6 murders $\left(4,7,2^{\text {nd }}\right.$ and $\left.3^{\text {rd }} \mathrm{DMs}\right)$.

Serial killers use several methods of killing including strangulation, stabbing, cutting, blunt-force trauma and firearm injuries. ${ }^{[11]}$ In this series, except for firearms, the remaining methods had been used. The 2010 suspect used 3 methods to kill 3 women; manual strangulation, cut injuries to the head and blunt force trauma to the head. The 2015 suspect had used 2 methods to kill 6; ligature strangulation in 2 cases, cut injuries to head in 4 cases. Of them, in one (case 7) had short deep cut injuries and the murderer had probably used an axe.

After the sexual act, some serial killers attempt to remove sexual evidence in serial killings. ${ }^{[6]}$ Similarly, bodies of case 2 and 15 were dumped in the water. Though the $13^{\text {th }}$ body was burnt, the fluid samples accumulated in deep vagina appeared to have protected protein traces from heat effects.

In serial killing, some bodies are left at the scene and some are moved. In this series, out of 13 potential serial murders ( $2^{\text {nd }}, 3^{\text {rd }}$ and $4^{\text {th }}$ clusters $), 9$ were left at home. When an offender leaves a body at the scene, it can be left as it is or the offender may position the body in a bizarre or suggestive manner or may attempt to conceal the victim at the scene. ${ }^{[6]}$ In this series, the position of case 2 suggested sexual orientation and in 5 cases (case $5,2^{\text {nd }} \mathrm{DM}$ and $3^{\text {rd }} \mathrm{DM}$ ), there were attempts to conceal those crimes by burning.

Out of 13 potential serial murders, the offender had moved the body from the site of killing in four cases. If an offender moves a body away from the murder site, one of the three following scenarios can occur: the body can be dumped, concealed, or displayed. ${ }^{[11]}$ In this series, two bodies were dumped in the jungle (case 6 and 7), one was dumped in the water (case 2) and one concealed by burial (case 4). None of the bodies was kept for display.

This is not the first time that serial killers are reported in Sri Lanka. In 2003 a mobile vendor, from Kandy, killed several women and he could be the first serial murderer in the recent criminal history of Sri Lanka. ${ }^{[12]}$ From 2010-2011, 14 beggars were found to have been killed with head injuries, on the pavements of Colombo by another beggar and he could be the highest potential serial killer in Sri Lanka ${ }^{[13]}$ In the current series, there should be two or more serial killers in Kahawatta, Ratnapura, Sri Lanka.

However, the $1^{\text {st }}$ cluster ( $1^{\text {st }} \mathrm{DM}$, and case 15 and 16$)$ were committed for personal reasons by known offenders and were excluded from serial killings. Further, in the $1^{\text {st }}$ cluster, three special features have been identified. 
(i) Some used this situation to kill their enemies and attempted to mimic serial killings, for example, the $1^{\text {st }} \mathrm{DM}$ was connected to a drug deal and case 15 was committed following a personal problem at the Kovil.

(ii) Case 16 appeared to be a copycat murder. In copycat murders, they use the knowledge received by media of previous killings and make the scene and the body similar to serial murders and tries to mislead the investigators. ${ }^{[14,15]}$ In case 16 , the son killed the mother for not giving money to buy a present for his girlfriend. However, the son did not stop his mission by killing his mother, he then dumped the body in Kotakethana canal. Therefore, it is compatible with a copycat murder.

(iii) Thirdly, out of three double murders, the latter two were initially suspected to be an alibi created by the suspects of the first double murder who were in custody.

In this investigation, DNA test played a crucial role. In 2012 , in respect of $3^{\text {rd }} \mathrm{DM}, 04$ suspects were arrested but did not match with DNA and were acquitted. At that time there was a public outcry on their acquittal, but in 2015, DNA was matched with the real suspect. Further, his DNA tallied with 6 murders. This highlights the importance of proper medicolegal investigation to avoid a miscarriage of justice.

\section{Conclusions}

The existing DNA database of Sri Lanka has been successfully used in the present series in linking multiple crimes and could be further expanded similar to the US database by including DNA profiles of all convicted individuals and suspects arrested for crimes of a serious nature.

The ability to "read" the crime scene, recognize the "signature" of an offender and link by DNA tests are extremely useful in the identification of a serial killer. Further, this is the first ever reported incident where two (02) or more serial killers operate in the same area in the same duration. Three special features found in this series include; some attempting to mimic serial killings, one appearing to be a copycat murder and in some instances appearing to be an alibi created by the suspects who were in the custody. Further, it took seven years to solve the unexplained serial crime. If the early arrest of suspects was done, the lives of many victims could have been saved. Therefore, the importance of the establishment of a "National Criminal Investigation Centre" with a database of unsolved crime records and a "National Automated DNA Data Base" to analyze all unsolved crimes, provide information for investigators, investigate such unsolved crimes, and also to advise lawmakers is reiterated.

\section{Reference}

1. Adjorlolo S, Choon $\mathrm{CH}$. The controversy of defining serial murder: Revisited. Aggression and Violent Behavior 2014;19(5): 486-491

2. Morton RJ, McNamara JJ. Serial murder. In: Payne-James J, Byard R, Corey T, Henderson C. Encyclopedia of forensic and legal medicine. $1^{\text {st }}$ ed. Vol 4. Boston: Elsevier Academic Press; 2005. p.48-52.

3. Hickey EW. Serial Murderers and their victims. $5^{\text {th }}$ ed. Belmont, USA: Wadsworth; 2010.

4. Keppel RD, Birnes WJ. The Psychology of Serial Killer Investigations, The Grisly Business Unit. San Diego, CA: Academic Press; 2003.

5. Keppel RD. Signature Killers: Interpreting the Calling Cards of the Serial Murderer. New York: PocketBooks; 1997.

6. Geberth VJ, Turco RN. Antisocial personality disorder, sexual sadism, malignant narcissism, and serial murder. J Forensic Sci 1997;42(1):4960.

7. Schlesinger LB, Kassen M, Mesa VB, Pinizzotto AJ. Ritual and signature in serial sexual homicide. J Am Acad Psychiatry Law 2010; 38(2):239-46.

8. Dietz PE. Mass, serial and sensational homicides. Bull N Y Acad Med 1986; 62(5):477-91.

9. Coyle J, Ross KF, Barnard JJ, Peacock E, Linch CA, Prahlow JA. The eyeball killer: serial killings with postmortem globe enucleation. J Forensic Sci. 2015 May; 60(3):642-7.

10. Eberth VJ. Practical Homicide Investigation: Tactics, Procedures, and Forensic Techniques. $5^{\text {th }}$ ed. Boca Raton, Florida: CRC Press Inc.; 2015.

11. Ochberg FM, Brantley AC, Hare RD, Houk PD, Ianni R, James $\mathrm{E}$, et al. Lethal predators: psychopathic, sadistic, and sane. Int J Emerg Ment Health 2003; 5(3):121-36.

12. Lankaweb [homepage on internet]. Jayatunge RM, Serial Killers and the Sri Lankan Society [updated 2011 Aug 29; cited 2017 Jan 06] ethylene glycol poisoning increase after media coverage of antifreeze murders. West J Emerg Med 2011 Jul; 12(3):296-9.

13. Vidanapathirana $M$, Have thirteen beggars been killed by a serial killer? Galle Medical Journal 2013; Vol 18 (2):17-21

14. Coleman L, The copycat effect: How the media and popular culture trigger the mayhem in tomorrow's headlines, New York: Paraview pocketbooks; 2004. 
15. Morgan BW, Geller RJ, Kazzi ZN. Intentional ethylene glycol poisoning increase after media coverage of antifreeze murders. West J Emerg Med 2011 Jul; 12(3):29 